\title{
Advantages of Employment after Retirement - A Content Analysis Approach. What Is Academic Professional Experience Worth After Retirement Age?
}

\author{
Nitza Davidovitch ${ }^{1} \&$ Eyal Eckhaus ${ }^{2, *}$ \\ ${ }^{1}$ Department of Economics \& Business Administration, Ariel University, Ariel, Israel \\ ${ }^{2}$ Head of Academic Quality and Assessment, Head of Teacher Training Program, Ariel University, Israel \\ *Correspondence: Department of Economics \& Business Administration, Ariel University, Ariel, Israel. E-mail: \\ eyale@ariel.ac.il
}

Received: October 24, 2019

Accepted: November 21, 2019 Online Published: December 18, 2019

doi:10.5430/wje.v9n6p65

URL: https://doi.org/10.5430/wje.v9n6p65

\begin{abstract}
This study is a pioneer study that examines the advantages of faculty employment after retirement age from the perspective of academic faculty. The economic-industrial literature suggests that prior experience is a major consideration in the industry, particularly in the process of selecting suppliers, and the weight given to occupational experience has an effect on other advantages as well.

108 questionnaires administered to senior faculty were collected in a case study of a single university. A combined research method including qualitative and statistical analyses was employed, with the aim of exploring the advantages of faculty employment at institutions of higher education after retirement age.

The current research findings show that most of the faculty members claim that the experience accumulated by faculty who have passed the retirement age is their strongest advantage. Furthermore, professional-academic experience was found to correlate with other advantages, namely knowledge, international contacts, deeper familiarity with the global academic system, improved teaching capabilities, and improved ability to guide advanced studies. This, in addition to the advantages of personal-professional skills: more patience and greater research performance ability.

The findings raise the practical question of the implications for the academic system in general and for the public academic system in particular. In other words, how does the public system of higher education translate the advantages of previous academic experience beyond retirement age? What are the benefits for colleagues, young faculty, the institutions - and the system of higher education in general, with regard to research, teaching, and contribution to the community?
\end{abstract}

Keywords: retirement age, retirement, employment, retirement, academic faculty

\section{Introduction}

\section{1 “Academic Capitalism" and Its Effect on Israel's System of Higher Education}

The phenomenon of academic capitalism emphasizes the aspect of profit and loss within the considerations taken into account by educational institutions. Decisions reached on academic topics consider elements of collaboration between academia and industry, the commercialization of knowledge, locating investors, integrating entrepreneurs, management efficacy, and changing the academic culture (Hoffman, 2011).

The system of higher education, as an educational institution, constitutes another aspect of humans' social existence. On the sociological dimension, processes undergone by higher education are part of a wide social context that is also manifested in the academic domain. Examination of economic, political, social, statutory, and demographic processes illuminates changes that have occurred in the system of higher education as part of sociological trends that filter through the walls of institutions of higher education and affect their image (Davidovitch, Lobova, Pryamikova, Pechenkina, \& Yachmeneya, 2012). 
From an economic perspective, the expansion of higher education is a product of the exchange economy that was later transformed into the capitalist economy. According to the economic ideology, changes in the nature of the economy led to redefinition of the individual, who became a potential producer, and as taxpayers the state is responsible for giving individuals the tools and authority to manage their productive activity. From this point of view, education is an element that increases the individual's productivity as well as the state's indirect profits. This perception sees the educated as human capital, while linking education with financial gain and well-being (Amaral \& Magalhaes, 2004).

Perceiving the educational system as an economic tool is nothing new and is the basis for the establishment of modern universities (Scott, 1995). Although this is most acutely evident in the late 2010s, its roots are in the late 19th century, with the rise of capitalism and the transition to thinking in terms of profit and loss (Scott, 2006). For years, research institutions were managed under a self-governing policy and kept their distance from external economic policies, however in time this approach managed to enter academic institutions as well and considerations of profit, efforts to integrate entrepreneurs, writing patents, collaboration with industry, and managerial efficacy acquired a central role (Hoffman, 2011). Similarly, Hoffman cites the change that occurred with the integration of new knowledge disciplines related to the global market, learning the culture of additional markets, and so on. In addition, the conceptual change and perceiving higher education as a means of economic growth and of developing industry epitomized the paradigmatic change that applied pressure on the universities to generate products. Where in the past academia was not part of the business world, keeping to its own matters and remaining on the margins of the social world, in the 20th century its role changed significantly. Suddenly it was required to train skilled workers, produce applied research, and constitute an important part of advancing the nation. As a result, academia was compelled to make the transition to massive preparation of citizens for life in an advanced industrial society and to shift its educational emphasis from shaping the student's character and world to conveying certain skills and occupational training, as well as defining the aims and goals that can be expected of the graduates in terms of the academic "output" to be generated (Yadgar, 2007). Moreover, academia was required to appeal to new and disadvantaged population groups.

Academic capitalism set several challenges for universities, which included recruiting trained academics for commercial activity and giving priority to academic studies motivated by profit (Hoffman, 2011).

The economic changes that occurred primarily following the change in perception of academia as a capitalist institution were only one part of additional changes that took place and that included political, social, statutory, and demographic changes leading to the global growth of higher education (Levy, 2001).

This study is the first to examine the advantages of employing faculty members who have passed retirement age from the perspective of academic faculty. Previous experience was found to be the most important parameter in the process of supplier selection (Eckhaus, Kogan, \& Pearlman, 2013). Similarly, employers prefer more experienced job applicants (Buchs \& Helbling, 2016), and even with regard to senior positions, firms often prefer more experienced directors (Lu, Chen, \& Kao, 2017). This may also be the reason for the higher financial reward offered, compared to lower ranked employees (Eckhaus, Weber, Koppel, \& Spiegel, 2018). In line, merit principles suggest that governments should prefer more experienced workers (Lewis, Boyd, \& Pathak, 2018). Naturally, in teaching as well, experienced teachers are preferred (Salmon \& Sayed, 2016).

We shall relate to the economic dimension from the perspective of industrialist economists - is experience worth money? Why is it preferable to employ older people? The following is the opinion of Yehuda Modai, an economist, on this issue. Yehuda Modai (2011): "In one of the organizations where I worked I had a worker... with more than 15 years of experience, a worker who had already seen everything, done everything, and was surprised by nothing. Her experience in all aspects of her profession was an inestimable asset for the company, one that was often translated into revenues or reduced expenses...I often read about managers interested in lowering the age of their workers, or about the difficulties of finding work after the age of 50 or even much earlier. I read and see these things, but I do not understand. I could cite social arguments that one day we will all age and that they merit attention, but because I do not believe that a financial company acts to realize overall social visions rather only to maximize profits for its owners - I will not do so".

So why do I prefer older workers, or more accurately, think that age has no significance for considerations underlying the employment of workers? For pure business reasons:

- In any company in which I worked or that I visited a saw a backbone of veteran workers who are the soul of the business. All plants or offices have a veteran storekeeper who knows all the items by heart, a payroll accountant who knows the labor laws and the spirit of the law, or a shift head who sometimes forgets why something is done in a 
certain way but makes sure that the products are issued in perfect condition.

- These veteran/older workers are workers who have no absences to care for children and school vacations, workers who do not repeatedly check their situation and worth on the labor market every month or two, and knowing that their state of employment is seen as problematic by certain organizations they are exceptionally loyal workers and will not switch companies for a raise of several hundred shekels or a better company car.

Modai (2011) explains: “...So, I've heard of managers who prefer young workers with a fresh spirit and innovative ideas and claim that the energy of the young is preferable over the fixation of the old. I've heard but I was not impressed. I've seen many workers in all types of professions and of all ages, the only rule that I've managed to form is that there are no rules. "The world belongs to the young"? - The downside of young workers: I've seen workplaces that have only young people - a young atmosphere of... a train station. People come and go and the place has no character - and usually there is no family atmosphere. I wouldn't want to work at such a place, which usually (due to the considerable volatility) does not invest much in its workers and on the other hand also does not receive the added value of experience when there is need to integrate a better product in the market.

In my opinion the correct mix is having something of everything, a combination of young energies with mature experience - as in life. When I was accepted to an accountancy office as an intern - one of the partners said wisely in his guidance session before we left for a first company audit: "Don't think that they taught you everything at university. Listen to everything the "lowly" experienced accountants have to say, they know things that you didn't even know existed" - Respect experience - its worth money."

Prejudices shatter when they encounter reality. The common opinion in general and the opinion of employers in particular with regard to employing workers aged 45 and older is in complete contradiction to their great potential contribution.

The main problem is the negative stereotypical attitude to those of older age with regard to technological limitations, speed of performance, and poor energy, but quite a few studies show that this is not true. Here are five top reasons proving that older people are better workers.

Eran Kristal (2015) presents the five top reasons: Why it is worthwhile to employ older people:

i. There is a will and there is an ability to learn

Transitioning to the progressive era - Quite a few employers think that with regard to technological progress workers aged 45 and older cannot necessarily maintain the work pace and thus prefer to employ members of a generation that was "born" into current day technology.

There is no reason that a worker should be unable to apply technological progress, whether young or old. Where there is a will there is a way. Indeed, it takes older people more time to learn new material but the cost of training them is still lower due to their aptitude for learning and the experience they accumulated throughout life.

ii. Surprisingly, few vacation and sick leave days

Leisure and free time - It is precisely workers of advanced age that have more time to work because their children are already at an age when they can care for themselves and mature enough to make their own decisions without involving their parents.

This creates a situation where the worker can focus and concentrate on the job without needing to take sick leave or time off for their children's vacations. In addition, the total number of sick leave days utilized by older people is lower than that of other age groups. Moreover, older people take less risks and their accident rates are statistically lower than those of other age groups.

iii. They are not on the lookout for their next job

Stability - Older workers are perceived as more stable and they are not volatile like the Y generation - known to switch jobs constantly, creating significant costs for employers who must repeatedly recruit and train new workers. The output of the older population is among the most stable of all age groups.

iv. Experience worth its weight in gold

Significant experience - Older workers have a great deal of occupational experience as well as life experience that is very helpful in making important decisions and that is worth a great deal of money for employers.

Occupational experience can bring the organization new work methods and ideas that will take the business forward.

v. They aim for the organization's good (Ogba, 2008) 
The purpose of this article is to expand the previous study on workers' commitment to the organization. This article intends to use income and age as variables for assessing workers' commitment to their organizations in Nigeria. Results of the analysis show that workers with a high income represent those workers in the 31-35 age group who have low commitment to their organization. This article demonstrates the associations between age and income. Commitment can be explained by referring to cultural elements that might have a stronger effect on workers' expressions of commitment to their organization. The findings show that:

Responsible judgment and a can-do attitude. Older workers have better judgment than the young and are more capable of avoiding hurried and irresponsible decisions that often come at a high price.

They are less inclined to speak harshly and to get caught up in ego conflicts. The outlook of older people is one that aims for the organization's good and therefore they constitute a link for all activity across departments and serve as an asset.

This is a quality group of people who come with the intention of applying themselves to their work. Obviously, we will all be older one day so why shouldn't we invest in this group in the present and then all profit in the future?

\subsection{Experience and Seniority Contribute to Output (Holzer, 1988)}

A report by the American Bureau of Statistics (Tur-Sinai, 2016) shows that in the next decade most of the growth within organizations will be produced by workers aged $65+$.

Moreover, data published by the OECD (2015) show (Tur-Sinai, 2016) that Americans aged 55 and older constitute only slightly less than one quarter of the country's workforce, but nevertheless last year they occupied nearly half of the 2.9 million jobs obtained, which is the largest segment of all age groups.

The OECD anticipates that this trend will persevere. The report indicates that life expectancy is on the rise and that the number of children born is declining.

Productivity rates in the US, Britain, Germany, Japan, and almost all other developed countries, are lower than the turnover rate between younger and older generations. The result is that the average age is rising both in general and in the workforce.

The main problem is that most employers are not enthusiastic, to say the least, about employing older workers. Why?

- The main reason, as shown in the report, is that although older workers might have more experience and knowledge, they usually also earn higher salaries than younger workers.

- Many employers believe that older workers cannot work at today's digital work pace.

The result is that older age is considered a shortcoming in the labor market, and when organizations are required to choose between an older and experienced worker and a young worker who lacks experience, in many cases they prefer the younger workers.

This is a discriminatory approach that is banned in many developed countries.

Despite the laws intended to protect older workers, more and more older workers are compelled to retire because they cannot find jobs in companies. Furthermore, according to the current law in Israel, workers who have passed the mandatory retirement age are not entitled to receive the protection of the law against age-based discrimination.

Other studies conducted in the US show that over 50 percent of workers aged 50 and older lose their jobs before they are ready to retire.

Of those who are not compelled to retire, some 90 percent will never be able to maintain their previous earning capacity due to the low demand for them as workers.

Many companies are being sued at present, around the world as well as in Israel, for age-based discrimination, companies who notify candidates that they are too old for a specific job even when age is irrelevant for carrying out the responsibilities required by the job.

Other companies think that they can circumvent the law by defining the job requirements as less than seven years' experience (or no more than seven years) or by defining jobs as intended for students or university graduates from the last year or two.

All these excuses lead the organizations to the courts, which usually rule that they must pay compensation for discrimination. Even Facebook was compelled to remove its age criterion.

Nevertheless, studies show that the labor world will soon undergo an essential change with regard to employing older 
people. The forbidden age-based discrimination is diminishing due to occupational diversity programs. In addition, employers are discovering that they truly need older workers due to the growing discrepancy between the demand and supply of skilled workers.

Mega-corporations in the US, including Boeing, Apple, large banks, and others, are inviting retirees to come and work for them, and providing them with training and new skills, although in many cases these are still part-time positions.

Company managements must remember that many citizens aged 50 and older usually have more free income than the young, and therefore their purchasing power is several times higher than that of the younger generation. These consumers want to do business with organizations that respect older people and that do not see older age as a negative quality.

Accordingly, human resource managers would do well to act to eradicate age-based discrimination and to recognize the enhancement of generational diversity as an important goal.

Research rationale

In light of the research literature and the bills proposed on this topic, the current research hypotheses are that:

H1. Experience positively affects knowledge.

H2. Experience positively affects connections in the academic environment.

H3. Experience positively affects knowledge of the academic system.

H4. Experience positively affects teaching capabilities.

H5. Experience positively affects guidance capabilities.

H6. Knowledge positively affects connections in the academic environment.

H7. Patience positively affects teaching capabilities.

H8. Research capabilities positively affect guidance capabilities.

\section{Method}

\subsection{Initial Sample}

A questionnaire was distributed for the purpose of data collection, with a single open-ended question: "In your opinion, what are the unique advantages that a faculty member who has passed retirement age may have, compared to a younger faculty member?". Demographic data regarding age and gender were collected.

The questionnaires were distributed to the senior faculty members at Ariel University, Israel, using Google Docs. One hundred and eight completed questionnaires were collected. Of all respondents, $47.6 \%$ were females and $52.4 \%$ males. The age range was 36-49 (36.6\%), 50-60 (32.3\%), and 61-84 (31.2\%).

\subsection{Analysis}

First, the known process of text categorization was performed (Bruce \& Wiebe, 1999), a manual analysis process where all texts are read and major themes are identified and tagged (Davidovitch \& Eckhaus, 2018; Eckhaus \& Davidovitch, 2018a, 2018b). Based on these major themes a model was constructed. Most respondents (82 of 108) specified that experience (EXP) is the most dominant advantage. The rest of the advantages were: patience (PAT), knowledge (KNW), connections worldwide (CON), research capabilities (RES), guidance capabilities (GUI), teaching capabilities (TEA), and knowledge of the academic system (ACD). Categories were coded using the binary system (Eckhaus \& Sheaffer, 2018b); responses were tagged 0 when they did not belong to the category, and 1 when they did. A mixed methods research design (Cortini, 2014), which provides the strengths of both the qualitative and empirical methods, and offers a better understanding of the research question, was employed (Davidovitch \& Eckhaus, 2019a, 2019b; Eckhaus \& Davidovitch, 2019). That is, while the core study is empirical and based on statistical investigation, we combined qualitative analysis and examples from respondents, to strengthen the validity of the results.

In order to test the model's goodness-of-fit we used Structural Equation Modeling (SEM) (Eckhaus, 2019a; Eckhaus \& Sheaffer, 2018a), a powerful multivariate technique (Eckhaus, 2019b). The measurements criteria used for model fit were CMIN/DF, CFI, NFI, TLI, and RMSEA. Values of CFI, NFI, and TLI $\geqslant .95$ and RMSEA $<.06$ are indication of a good fit (Schreiber, Nora, Stage, Barlow, \& King, 2006), the CMIN/DF ratio should be $<3$ (Stegers - 
Jager, Cohen - Schotanus, \& Themmen, 2012). However, some scholars argue that CMIN/DF should be $<2$.

\section{Qualitative Examples from Respondents}

Research experience as perceived by faculty - what is it?

Research experience

- Considerable research efforts

- Connections with researchers at the university and around the world

- Connections, research/professional maturity

- Knowledge accumulated

- Patience, more thorough familiarity with the content worlds

- Greater seniority and ability to publish

- More knowledge of the research discipline and more time to devote to research

Teaching experience

- Wide teaching knowledge

- Greater knowledge, improved teaching capabilities

- Experience in guidance and teaching

- More experience in teaching, familiarity with the system, and greater maturity in writing articles

Contribution to the community

- Academic and managerial experience, ability to organize study days, preparing lectures

Personality

- Patience

- Thoroughness

- Less pressure to produce output for purposes of promotion and more for other important causes

\section{Empirical Results}

Spearman's correlations, means, and SD are presented in Table 1. The model and the results are illustrated in Figure 1 .

Table 2. Correlation Matrix: Means and SD

\begin{tabular}{|c|c|c|c|c|c|c|c|c|}
\hline & $E X P$ & $P A T$ & $K N W$ & $C O N$ & RES & $G U I$ & $T E A$ & $A C D$ \\
\hline$E X P$ & - & & & & & & & \\
\hline$P A T$ & -.01 & - & & & & & & \\
\hline$K N W$ & $.27 *$ & -.06 & - & & & & & \\
\hline$C O N$ & .07 & -.05 & $.24 *$ & - & & & & \\
\hline RES & .12 & .13 & .03 & -.13 & - & & & \\
\hline$G U I$ & .09 & .07 & -.02 & .06 & $.27 * *$ & - & & \\
\hline$T E A$ & $.21^{*}$ & $.23 *$ & -.1 & -.01 & $.44 * * *$ & $.21^{*}$ & - & \\
\hline$A C D$ & $.23^{*}$ & -01 & .15 & .17 & -.001 & .12 & .06 & - \\
\hline Mean & 1.56 & .24 & .45 & .26 & .44 & .19 & .30 & .17 \\
\hline SD & 7.9 & 1.13 & 2.35 & 1.38 & 2.32 & 1 & 1.57 & .90 \\
\hline
\end{tabular}




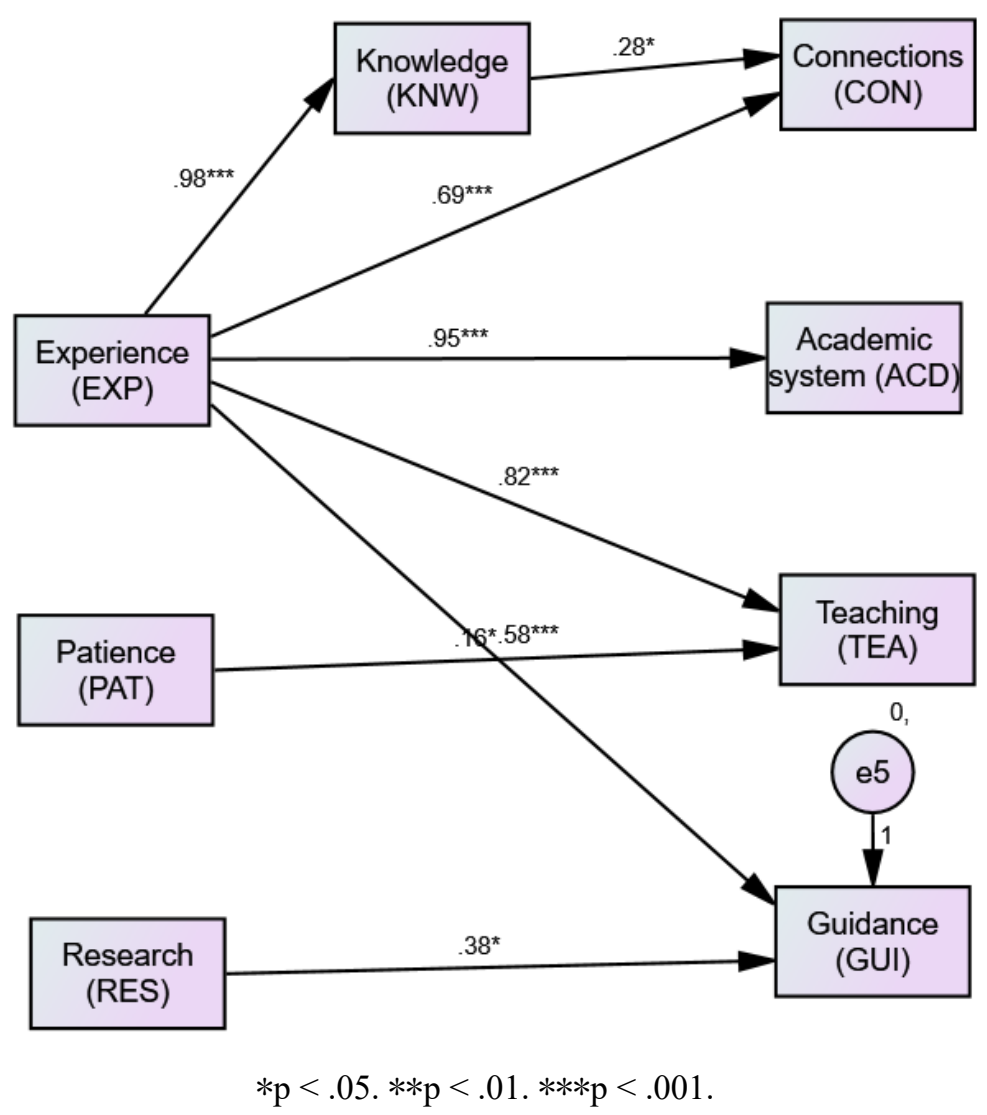

Figure 1. Model Results

The hypothesized model showed an excellent fit: $\mathrm{CMIN} / \mathrm{DF}=.76(\mathrm{p}>.05), \mathrm{CFI}=1, \mathrm{NFI}=1, \mathrm{TLI}=1.01, \mathrm{RMSEA}=0$. All hypotheses were supported. EXP positively affected KNW (H1), CON (H2), ACD (H3), TEA (H4), and GUI (H5), respectively. KNW positively affected CON (H6), PAT positively affected TEA (H7), and RES positively affected GUI (H8).

Next, we examined whether age and gender affect experience. Accordingly, a relationship was added between Age and Gender to Experience (EXP). Results showed no statistical significance of these new relationships.

\section{Discussion}

In line with previous literature, the results of this study underline the importance of experience as a parameter affecting other varied advantages. While other advantages of the senior faculty exist, such as patience and research capabilities, experience is the most valuable. Experience in academia means having accumulated more knowledge, connections, teaching practice, and guidance practice, as well as familiarity with the academic system. Along with these important benefits, with age come patience and research capabilities, which add additional value to the researcher's contribution to the institution.

The research findings raise the practical question of their implications for the academic system. Namely, how does the system of higher education translate the advantages of previous academic experience beyond retirement age? What are the "benefits" for colleagues, young faculty, the institutions - and the system of higher education in general, with regard to research?

Considerable research efforts, connections with researchers at the university and around the world, connections, research/professional maturity, accumulated knowledge, patience, more thorough familiarity with the content worlds, greater seniority and ability to publish, as well as more knowledge in the research discipline and more time to devote to research? 
What are the "benefits" for colleagues, young faculty, the institutions - and the system of higher education in general, with regard to academic teaching? Wide teaching knowledge, improved teaching capabilities, experience in guidance and teaching, familiarity with the system, and greater maturity in writing articles.

And finally, what are the "benefits" for colleagues, young faculty, the institutions - and the system of higher education in general, with regard to contribution to the academic community? With regard to academic and managerial experience, ability to organize study days and to prepare lectures?

With the extension of life expectancy in general, and in light of the fact that the academic profession is not a "physical" one and facilitates work in flexible conditions and spaces, there is room to examine the contribution of academic experience beyond retirement age, which was established 130 years ago.

Moreover, faculty who find themselves outside the public system of higher education, which ends their employment, find occupation in the private system of higher education and are helping build the private colleges, both in positions of academic leadership and as faculty members.

The research findings raise the practical question of their implications for the academic system. Namely, how does the system of higher education translate the advantages of previous academic experience beyond retirement age? What are the "benefits" for colleagues, young faculty, the institutions - and the system of higher education in general, with regard to research, teaching, and contribution to the community?

\section{References}

Amaral, A., \& Magalhaes, A. (2004). Epidemiology and the Bologna saga. Higher Education, 48, 79-100. https://doi.org/10.1023/B:HIGH.0000033766.02802.92

Bruce, R. F., \& Wiebe, J. M. (1999). Recognizing subjectivity: a case study in manual tagging. Natural Language Engineering, 5(2), 187-205. https://doi.org/10.1017/S1351324999002181

Buchs, H., \& Helbling, L. A. (2016). Job opportunities and school-to-work transitions in occupational labour markets. Are occupational change and unskilled employment after vocational education interrelated? Empirical Research in Vocational Education and Training, 8(1), 1-17. https://doi.org/10.1186/s40461-016-0044-x

Cortini, M. (2014). Mix-method research in applied psychology. Mediterranean Journal of Social Sciences, 5(23), 1900-1905. https://doi.org/10.5901/mjss.2014.v5n23p1900

Davidovitch, N., \& Eckhaus, E. (2018). The influence of birth country on selection of conference destination employing natural language processing. Higher Education Studies, 8(2), 92-96. https://doi.org/10.5539/hes.v8n2p92

Davidovitch, N., \& Eckhaus, E. (2019a). Student evaluation of lecturers - what do faculty members think about the damage caused by teaching surveys? Higher Education Studies, 9(3), 12-21. https://doi.org/10.5539/hes.v9n3p12

Davidovitch, N., \& Eckhaus, E. (2019b). Teaching students to think - faculty recommendations for teaching evaluations employing automated content analysis. International Journal of Higher Education, 8(3), 83-93. https://doi.org/10.5430/ijhe.v8n3p83

Davidovitch, N., Lobova, E., Pryamikova, E., Pechenkina, T., \& Yachmeneva, M. (2012). Expectations, practices, and preferences of college students - a cross-cultural perspective. CIS-Israel. Journal of International Education Research, 8(3), 41-49. https://doi.org/10.19030/jier.v8i3.7113

Eckhaus, E. (2019a). Happiness in fashion. In J. Kantola, S. Nazir, \& T. Barath (Eds.), Advances in Human Factors, Business Management and Society. AHFE 2018. Advances in Intelligent Systems and Computing, 783, 15-25. Cham: Springer International Publishing.

Eckhaus, E. (2019b). How to be happy. Blog section on www.artistila.com. Retrieved from http://www.artistila.com/how-to-by-happy/

Eckhaus, E., \& Davidovitch, N. (2018a). Impact of gender and conference size on conference preferences employing natural language processing. International Journal of Educational Methodology, 4(1), 45-52. https://doi.org/10.12973/ijem.4.1.45

Eckhaus, E., \& Davidovitch, N. (2018b). Improving academic conferences - criticism and suggestions utilizing natural language processing. European Journal of Educational Research, 7(3), 445-450. 
https://doi.org/10.12973/eu-jer.7.3.445

Eckhaus, E., \& Davidovitch, N. (2019). How do academic faculty members perceive the effect of teaching surveys completed by students on appointment and promotion processes at academic institutions? A case study. International Journal of Higher Education, 8(1), 171-180. https://doi.org/10.5430/ijhe.v8n1p171

Eckhaus, E., \& Sheaffer, Z. (2018a). Factors affecting willingness to contribute goods and services on social media. The Social Science Journal, 56(3), 390-400. https://doi.org/10.1016/j.soscij.2018.08.001

Eckhaus, E., \& Sheaffer, Z. (2018b). Happiness enrichment and sustainable happiness. Applied Research in Quality of Life. https://doi.org/10.1007/s11482-018-9641-0

Eckhaus, E., Kogan, K., \& Pearlman, Y. (2013). Enhancing strategic supply decisions by estimating suppliers' marginal costs. Journal of Supply Chain Management, 49(4), 96-107. https://doi.org/10.1111/j.1745-493X.2012.03277.x

Eckhaus, E., Weber, M., Koppel, M., \& Spiegel, U. (2018). Inequalities among employees with respect to their contributions and rewards. E-Journal of Social \& Behavioural Research in Business, 9(1), 1-9.

Eran Kristal. (2015). 5 Winning Reasons: Why You Should Employ Adults. [In Hebrew] Retrieved August 13, 2015 from https://www.ynet.co.il/articles/0,7340,L-4681674,00.html

Hoffman, A. J. (2011). Thirty-five years of research on business and the natural environment. Part 1: A statistical synopsis. Retrieved from http://oneaomonline.blogspot.com/2011/07/thirty-five-years-of-research-on.html

Holzer, J. H. (1988). The determinants of employee productivity and earnings: Some new evidence. NBER Working Papers 2782, National Bureau of Economic Research, Inc. Retrieved from https://www.hrus.co.il/\%D7\%9C\%D7\%9E\%D7\%94-\%D7\%9B\%D7\%93\%D7\%90\%D7\%99-\%D7\%97\%D7\%A 9\%D7\%95\%D7\%91-\%D7\%95\%D7\%A8\%D7\%A6\%D7\%95\%D7\%99-\%D7\%9C\%D7\%94\%D7\%A2\%D7\%A1 \%D7\%99\%D7\%A7-\%D7\%99\%D7\%95\%D7\%AA\%D7\%A8-\%D7\%A2\%D7\%95\%D7\%91\%D7\%93\%D7\%99 $\% \mathrm{D} 7 \% 9 \mathrm{D} /$

Levy, B. R. (2001). Eradication of ageism requires addressing the enemy within. Gerontologist, 41, 578-579. https://doi.org/10.1093/geront/41.5.578

Lewis, G. B., Boyd, J., \& Pathak, R. (2018). Progress toward pay equity in state governments? Public Administration Review, 78(3), 386-397. https://doi.org/10.1111/puar.12897

Lu, C.-S., Chen, A., \& Kao, L. (2017). How product market competition and complexity influence the on-job-learning effect and entrenchment effect of board tenure. International Review of Economics \& Finance, 50, 175-195. https://doi.org/10.1016/j.iref.2017.04.002

OECD (2015). OECD employment outlook 2015. Paris: OECD Publication Press.

Ogba, I. (2008). Commitment in the workplace: the impact of income and age on employee commitment in Nigerian banking sector. Management Research News, 31(11), 867-878. https://doi.org/10.1108/01409170810913051

Salmon, T., \& Sayed, Y. (2016). Teacher governance reforms and social cohesion in South Africa: from intention to reality. Education as Change, 20(3), 38-56. https://doi.org/10.17159/1947-9417/2016/1516

Schreiber, J. B., Nora, A., Stage, F. K., Barlow, E. A., \& King, J. (2006). Reporting structural equation modeling and confirmatory factor analysis results: A review. The Journal of Educational Research, 99(6), 323-338. https://doi.org/10.3200/JOER.99.6.323-338

Scott, J. (2006). The mission of the university: medieval to postmodern transformations. Journal of Higher Education, 77, 1-39. https://doi.org/10.1353/jhe.2006.0007

Stegers - Jager, K. M., Cohen - Schotanus, J., \& Themmen, A. P. (2012). Motivation, learning strategies, participation and medical school performance. Medical Education, 46(7), 678-688. https://doi.org/10.1111/j.1365-2923.2012.04284.x

Tur-Sinai, A. (2016). Employment and retirement among senior citizens in Israel: Main economic features. Jerusalem: Information Center for Research on Aging in the Israeli Population, Hebrew University. [Hebrew]

Yadgar, A. (2007). Crisis and change in higher education and how research universities in Israel cope. Tel Aviv.

Yehuda Modai. (2011). Experience is worth money: Why is it better to hire adults. [In Hebrew]. Retrieved February 10, 2011 from https://www.ynet.co.il/articles/0,7340,L-4026532,00.html 